Original Research

\title{
Effective Monitoring and Evaluation of Grain for Green Project in the Upper and Middle Reaches of the Yangtze River
}

\author{
Zuying Liu", ${ }^{1,}$ Bing Wang', Yusen Zhao², Xiang Niu ${ }^{1 *}$ \\ ${ }^{1}$ Research Institute of Forest Ecology, Environment and Protection, Chinese Academy of Forestry, Beijing, China \\ ${ }^{2}$ Northeast Forestry University, Harbin, China
}

Received: 3 December 2017

Accepted: 10 February 2018

\begin{abstract}
A comprehensive analysis of normalized difference vegetation index (NDVI), land-use type, and digital elevation model (DEM) data by using the geographic information system (GIS) showed that the index had increased over time in 84 prefectures that were part of the Grain for Green Project. SPOT Vegetation (Satellite Pour l'Observation de la Terre Vegetation, or satellite observation of the earth's vegetation) data and the NDVI showed that compared to 2000, in $20152.05 \%$ of the arable land in the study area was no longer cultivated and that $25 \%$ of the farmland with slopes steeper than $35^{\circ}$ and $2.68 \%$ of the moderately sloped farmland $\left(2-35^{\circ}\right)$ had been turned into forests. The arable land had been converted mainly to woodland and grassland. The interpretation of thematic mapper (TM) images showed that forest cover had increased significantly (by nearly 22\%); that vegetation cover was less than $10 \%$ over $95.27 \%$ of the area; and that the area with high vegetation cover had increased significantly. Superposition analysis of TM images and DEM data showed that the intensity of soil erosion had generally decreased, with the areas under mild and pole-strength soil erosion decreasing by more than $10 \%$. However, the Grain for Green Project has failed to check severe soil erosion so far. At present, although $60 \%$ of the study area is covered by forests, the extent of change in the degree of vegetation cover varied over time, and the spatial distribution was uneven, being higher in the east than in the west. It is therefore important to continue to strengthen governance through such projects.
\end{abstract}

Keywords: Grain for Green Project, land use style, soil erosion, NDVI, vegetation cover

\section{Introduction}

In recent decades, summer floods in southern China and drought in northern China have been more frequent than before. China also experiences severe sandstorms,

*e-mail: niuxiang@caf.ac.cn often attributed to unsustainable farming, uncontrolled grazing, and deforestation [1], which is why afforestation and reforestation efforts to mitigate wind erosion and water erosion are becoming particularly important for China [2]. The complex topography and geomorphology of the region comprising the upper and middle reaches of the Yangtze River lead to great spatial differences in hydrothermal conditions and to severe water 
erosion. Anthropogenic activity in the region has destroyed natural vegetation; such destruction, coupled with large areas that consist of steep slopes and are thus prone to severe soil erosion, requires sustained effort to reclaim the land. In the past, sustainable use of land and the environment had restricted the socio-economic development of the region, given its fragile ecology, frequent floods, and dangers posed by the flow of debris [1-10]. The Grain for Green Project (GGP), implemented in 1999, is one of the six major ecological projects in China and has protected and improved the ecology of the region, reduced the possibility of natural disasters such as landslides, and increased the vegetation cover. At the same time, the GGP has also transformed farming, making it more production intensive, and effectively improving the living standards of local farmers.

The most notable effect of the reforestation project is the increase in vegetation cover [11], apparent from the normalized difference vegetation index (NDVI) computed from a large-scale study. The index accurately reflects the photosynthetic intensity of vegetation, metabolic vigour, the degree of greenness and its seasonal and interannual variability, plant growth, biomass, vegetation cover, and other important indicators [12]. The index has been researched in depth and used in studying vegetation cover and changes in it. Vegetation restoration analysis results over different spatial and temporal scales [13-26] shows that the NDVI varies markedly with season and with location. Wang et al. [14], who studied the effects of climate change and human activity on vegetation cover in hilly areas of southern China, concluded that spatial and temporal variations in vegetation are the result of climate change and human activity, but also confirmed that projects that reconvert farmlands into forests and other projects that aim at ecological restoration significantly improve vegetation cover. Peng et al. [15] used the NDVI to show that the spread of vegetation cover in most areas across China increased significantly between 1982 and 2010. During that period, the NDVI increased significantly during the growth season (April-October), by 0.0007 per year, but the increase was slower during 2000-2010 than during 1982-1999. Piao [16] examined the interannual variation in China's NDVI from 1982 to 1999 and its relationship with climate variables (temperature and precipitation) and human activity, and found that monthly and seasonal NDVI had increased significantly during the study period. Yagoub [17] used MODIS (moderate-resolution imaging spectroradiometer) data to explore the climatic factors that influenced changes in land cover in Sudan from 2001 to 2013 and found that the NDVI was high in the south and the highest in the fall, followed by that in summer and winter[18]. Hao's [19] study of Beijing's ecological transformation and its relevance using Thematic Mapper (TM) and Operational Land Imager (OLI) images showed that vegetation in Beijing had both recovered and degraded: the recovery amounted to $6.33 \%$ in $2000-2005,10.08 \%$ in $2005-2010$, and $6.33 \%$ in 2010-2015, the corresponding degradations being $13.62 \%, 9.35 \%$, and $13.62 \%$. The area in which the GGP had been undertaken was used as the study area, and the growth of vegetation was estimated from 2000 to 2010. Zhang et al. [25] used the NDVI based on data from satellites working at two different times of Global Inventory Modeling and Mapping Studies (GIMMS), and SPOT VGT (SPOT Vegetation or Satellite Pourl' Observation de la Terre Vegetation), which is French for satellite observation of the earth's vegetation) as the index of vegetation cover in nearly 30 years of the Loess Plateau.

The researchers confirmed that the average annual NDVI for areas in which the average slope was greater than $15^{\circ}$ was significantly and positively correlated to time, and that the vegetation cover had increased over time. With the development of $3 \mathrm{~S}$ technology - which comprises Global Positioning System (GPS), remote sensing (RS), and geographic information system (GIS) changes in land use or land cover captured through highresolution satellite imagery are being increasingly used for monitoring dynamic changes in the environment. Both RS and GIS have proved particularly useful in evaluating the effects of reconverting farmlands into forests. In the past, research on the effects of the GGP was confined mostly to the yellow soil plateau and the Yellow River basin and was based on RS. The research showed that vegetation cover had improved and soil erosion effectively curbed [26-31]. Wang et al. reported that returning farmland to forest can strengthen the function of soil and water conservation in the region and thus can have the same effect as that of ecological restoration. Research by Peng et al. [32] showed that change in land use changes the nature and extent of vegetation cover, and Ibrahim [33] showed that increases in forest land and farmland can reduce the soil moisture index and is positively related to soil degradation. Thus, NDVI, land use type, soil erosion, and vegetation cover are appropriate indices for testing GGP. The basin of the Yangtze River was a key management area for controlling soil erosion and water erosion and a focus area of the GGP; however, hardly any research has been conducted on the contribution of the GGP to the protection and restoration of habitat on catchment scale in this region.

It is against this background that the NDVI supplemented with data on land-use type and slope for the same equivalent period - was selected for monitoring the efforts to restore vegetation in the middle and upper reaches of the Yangtze. More specifically, the objectives were to (1) study the spatial and temporal changes in vegetation cover in the study area and (2) to analyse and evaluate the effects of the GGP in the study area. 


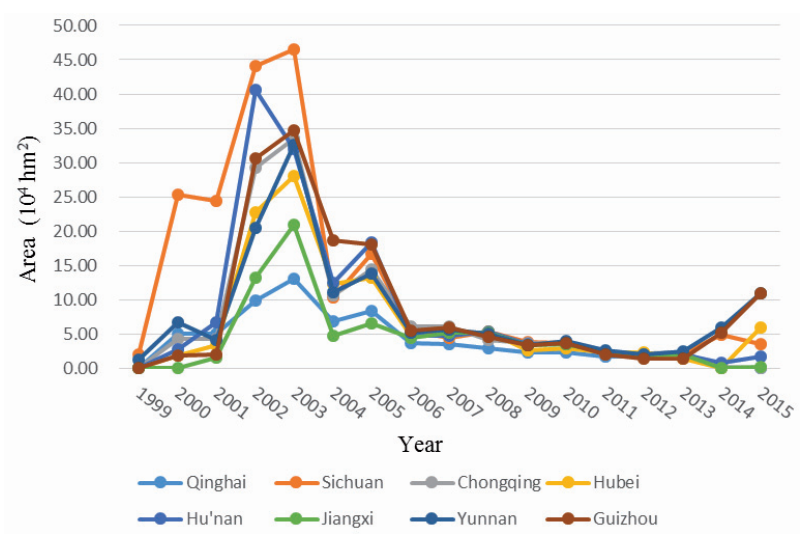

Fig. 1. Implementation area of Grain for Green Project in the middle and upper reaches of the Yangtze River (1999-2015).

\section{Material and Methods}

\section{The Study Area}

The provinces in the middle and upper reaches of the Yangtze in which the GGP is being implemented are Qinghai, Sichuan, Chongqing, Hubei, Hu'nan, Jiangxi, Yunnan, and Guizhou (Fig. 1), and consist of 84 prefectures and 763 counties. Since 1999, when the GGP was implemented on a pilot scale, the project has spread to 10.20 million $\mathrm{hm}^{2}$. The efforts to recover
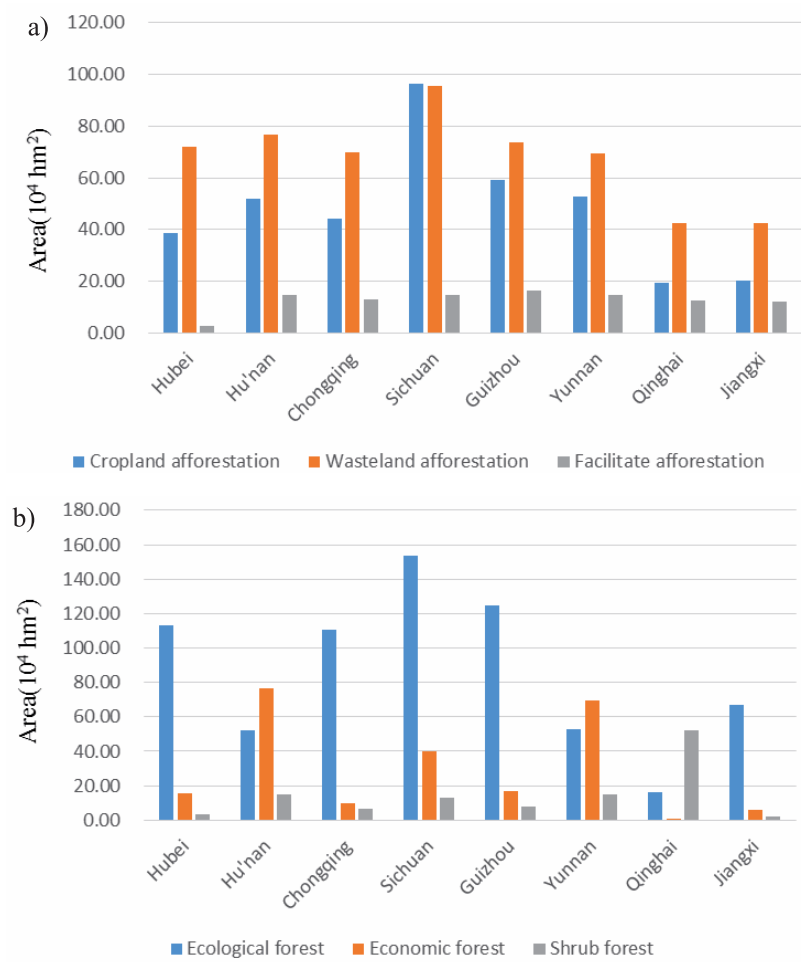

Fig. 2. Implementation area of Grain for Green Project for (a) three ways of increasing vegetation cover and (b) three types of forests in the middle and upper reaches of the Yangtze River (1999-2015) vegetation that are part of the GGP include afforestation of cropland and wasteland and encouraging afforestation of other areas. The forest types include ecological forests, commercial forests, and shrub forests [34]. In the middle and upper reaches of the Yangtze, the GGP gave priority mainly to the afforestation of cropland and wasteland, recovery of existing vegetation types, and setting up ecological forests (Fig. 2). Afforestation not only helped in soil conservation, water conservation, and the control of soil erosion, but also contributed to maintaining and improving the ecology of the upper reaches of the Yangtze basin.

\section{Research Methods}

\section{Data Source}

Land use, NDVI, and digital elevation model (DEM) data were provided by the Data Center for Resources and Environmental Sciences, Chinese Academy of Sciences (RESDC) (resdc.cn). The DEM data were the radar terrain mapping SRTM $90 \mathrm{~m}$ data from the U.S. space shuttle, and NDVI data (for 4 years, namely 2000, 2005, 2010, and 2015) were selected to maximize the NDVI based on the synthesis of SPOT VGT $1 \mathrm{~km}$ per $10 \mathrm{~d}$. The data set on vegetation index $(1 \mathrm{~km})$ in China since 1998 was compiled by taking the composite maximum value, of which the spatial resolution was $1 \mathrm{~km}$ and the temporal resolution was 1 year. The main source for the data on land-use status was Landsat TM/ETM remote sensing images, and land uses were categorized using the Land-Use and Land-Cover Change (LUCC) system and visual interpretation. The data on Chinese administrative divisions came from the State Bureau of Survey and Mapping (SBSM), and the diagram showing the scope of the GGP was supplied by the State Forestry Bureau [34].

\section{Calculating Vegetation Cover}

Vegetation cover refers to the ratio of the vertical projection area of a vegetation canopy to the total area of soil:

$$
\mathrm{f}=\left(N D V I-N D V I_{\min }\right) /\left(N D V I_{\max }-N D V I_{\min }\right)
$$

...where $\mathrm{f}$ represents vegetation cover; NDVI is the pixel vegetation index; and $\mathrm{NDVI}_{\max }$ and $\mathrm{NDVI}_{\min }$ are the vegetation indexes of pure vegetation and pure soil, respectively, and adopt the largest and the smallest approximation of NDVI in the monitoring area. Using Equation (1) to calculate the grid, maps of vegetation cover were obtained for 2000, 2005, 2010, and 2015.

\section{Determining Sloping Lands}

The data on DEM were re-projected and then selected so that they corresponded to the research area, and slope diagrams were generated using the spatial analyst tool of ArcGIS. The slopes were then reclassified, based 
Table 1. Classification standard of soil erosion intensity.

\begin{tabular}{|c|c|c|c|c|c|}
\hline \multirow{2}{*}{ Vegetation cover (\%) of non-cultivated land } & \multicolumn{5}{|c|}{ Slope ( $\left.{ }^{\circ}\right)$} \\
\cline { 2 - 6 } & $5-8$ & $8-15$ & $15-25$ & $25-35$ & $>35$ \\
\hline $60-75$ & \multicolumn{3}{|c|}{ Mild } & & \multicolumn{2}{|c|}{ Strong } & Pole strength \\
\hline $45-60$ & \multicolumn{2}{|c|}{ Moderate } & \multirow{2}{*}{ Pole strength } \\
\hline $30-45$ & & & Strong & Severe \\
\hline$<30$ & & & & \\
\hline Sloping & Mild & & & \\
\hline
\end{tabular}

on the Chinese national standard for the classification of soil erosion (SL190-2007), into six levels, namely $0-5^{\circ}, 8-15^{\circ}, 15-25^{\circ}, 25-35^{\circ}$, and greater than $35^{\circ}$. The raster data on cultivated land extracted from the land use data were superimposed on the gradient data to obtain information on farmland with different degrees of slope.

\section{Classifying Soil Erosion}

The middle and upper reaches of the Yangtze are dominated by water erosion, and the degrees of soil erosion in the study region in 2000, 2005, 2010, and 2015 were mapped (Table 1) using the Chinese national standards for the classification of soil erosion (SL190-2007). The data on vegetation cover were reclassified based on the extent of non-arable forest cover, as shown in Table 1, which was divided into the following categories: less than $30 \%, 30-45 \%, 45-60 \%$, $60-75 \%$, and greater than $75 \%$. We then extracted the raster data on woodlands and grasslands and overlaid those data with the data of vegetation cover after the reclassification.

\section{Results and Discussion}

\section{Annual Variation in NDVI}

The average values of the NDVI were 0.50 in 2000 , 0.53 in 2005, and 0.55 in both 2010 and 2015, showing the gradual but significant increase in vegetation cover. The increase was particularly noticeable during 2000-2005, but not so obvious during 2010-2015
(Fig. 1). Vegetation cover in the eastern part of the study area was greater, and its increase more obvious. The share of lands with vegetation cover greater than $70 \%$ was the largest during 2000-2005 (Table 2). This observation is consistent with the annual average NDVI. The share of lands with vegetation cover between 10\% and $50 \%$ decreased every year, whereas that of the lands with vegetation cover more than $50 \%$ increased. Removal of vegetation by people and through natural disasters was responsible for the vegetation cover being less than $10 \%$, although the area thus affected was limited. From 2010 to 2015 , the extent of area with vegetation cover below $10 \%$ increased significantly, a pattern different from that seen in the earlier blocks, mainly because of adverse climate and excessive deforestation.

\section{Changes in Land Use}

In 2000, cultivated land in the middle and upper reaches of the Yangtze occupied $7945.41 \mathrm{hm}^{2}$; by 2015, the area was down to $7782.83 \mathrm{hm}^{2}$ (Table 3). During 2000-2015, cultivated land in the middle and upper reaches of the Yangtze occupied 1,625,800 $\mathrm{hm}^{2}$, accounting for $2.05 \%$ of the cultivated land. Large tracts of cultivated land were converted into woodland or put to other uses. The extent of cultivated land decreased the most during 2010-2015, when it was down to $725,600 \mathrm{hm}^{2}$. In 2015, the area under forests increased by $119,000 \mathrm{hm}^{2}$ compared to that in 2000. During 2000-2005, the area under woodland increased by $292,900 \mathrm{hm}^{2}$ - only to decrease by $260,200 \mathrm{hm}^{2}$ during 2010-2015, mainly because of anthropogenic activity. The forest land degradation in the research area was obvious, but difficult to check; at the same time,

Table 2. Variation in the ratio (\%) of different degrees of slope to vegetation index in the upper and middle reaches of the Yangtze River.

\begin{tabular}{|c|c|c|c|c|c|}
\hline \multirow{2}{*}{ Year } & \multicolumn{5}{|c|}{ Ratio of degree of slope to vegetation index } \\
\cline { 2 - 6 } & $<10 \%$ & $10 \%-30 \%$ & $30 \%-50 \%$ & $50 \%-70 \%$ & $>70 \%$ \\
\hline 2000 & 8.58 & 22.81 & 10.40 & 26.71 & 31.50 \\
\hline 2005 & 8.27 & 21.67 & 9.24 & 15.56 & 45.26 \\
\hline 2010 & 6.78 & 22.35 & 9.03 & 14.28 & 47.56 \\
\hline 2015 & 12.39 & 19.46 & 7.96 & 11.78 & 48.40 \\
\hline
\end{tabular}


Table 3. Changes in area under different land uses in the upper and middle reaches of the Yangtze River.

\begin{tabular}{|c|c|c|c|c|c|c|}
\hline \multirow{2}{*}{ Year } & \multicolumn{7}{|c|}{ Area $\left(10^{4} \mathrm{hm}^{2}\right)$} \\
\cline { 2 - 7 } & Farmland & Woodland & Grassland & Water & Residential & Unused land \\
\hline 2000 & 7945.41 & 11337.57 & 17796.85 & 1304.17 & 526.34 & 6321.5 \\
\hline 2005 & 7888.18 & 11366.86 & 17779.39 & 1325.04 & 561.52 & 6310.93 \\
\hline 2010 & 7855.39 & 11375.49 & 17775.19 & 1331.76 & 588.41 & 6305.71 \\
\hline 2015 & 7782.83 & 11349.47 & 17749.98 & 1358.22 & 695.93 & 6295.53 \\
\hline
\end{tabular}

Table 4. Changes in the extent of farmland $\left(104 \mathrm{hm}^{2}\right)$ under different grades of slope in the upper and middle reaches of the Yangtze River.

\begin{tabular}{|c|c|c|c|c|c|c|}
\hline \multirow{2}{*}{ Year } & \multicolumn{6}{|c|}{ Slope } \\
\cline { 2 - 7 } & $<2^{\circ}$ & $2^{\circ}-6^{\circ}$ & $6^{\circ}-15^{\circ}$ & $15^{\circ}-25^{\circ}$ & $25^{\circ}-35^{\circ}$ & $>35^{\circ}$ \\
\hline 2000 & 5005.94 & 1943.28 & 882.10 & 102.53 & 5.60 & 0.04 \\
\hline 2005 & 4972.91 & 1927.42 & 875.17 & 101.25 & 5.52 & 0.04 \\
\hline 2010 & 4951.19 & 1920.75 & 871.54 & 100.59 & 5.48 & 0.03 \\
\hline 2015 & 4895.60 & 1907.96 & 867.90 & 100.10 & 5.45 & 0.03 \\
\hline
\end{tabular}
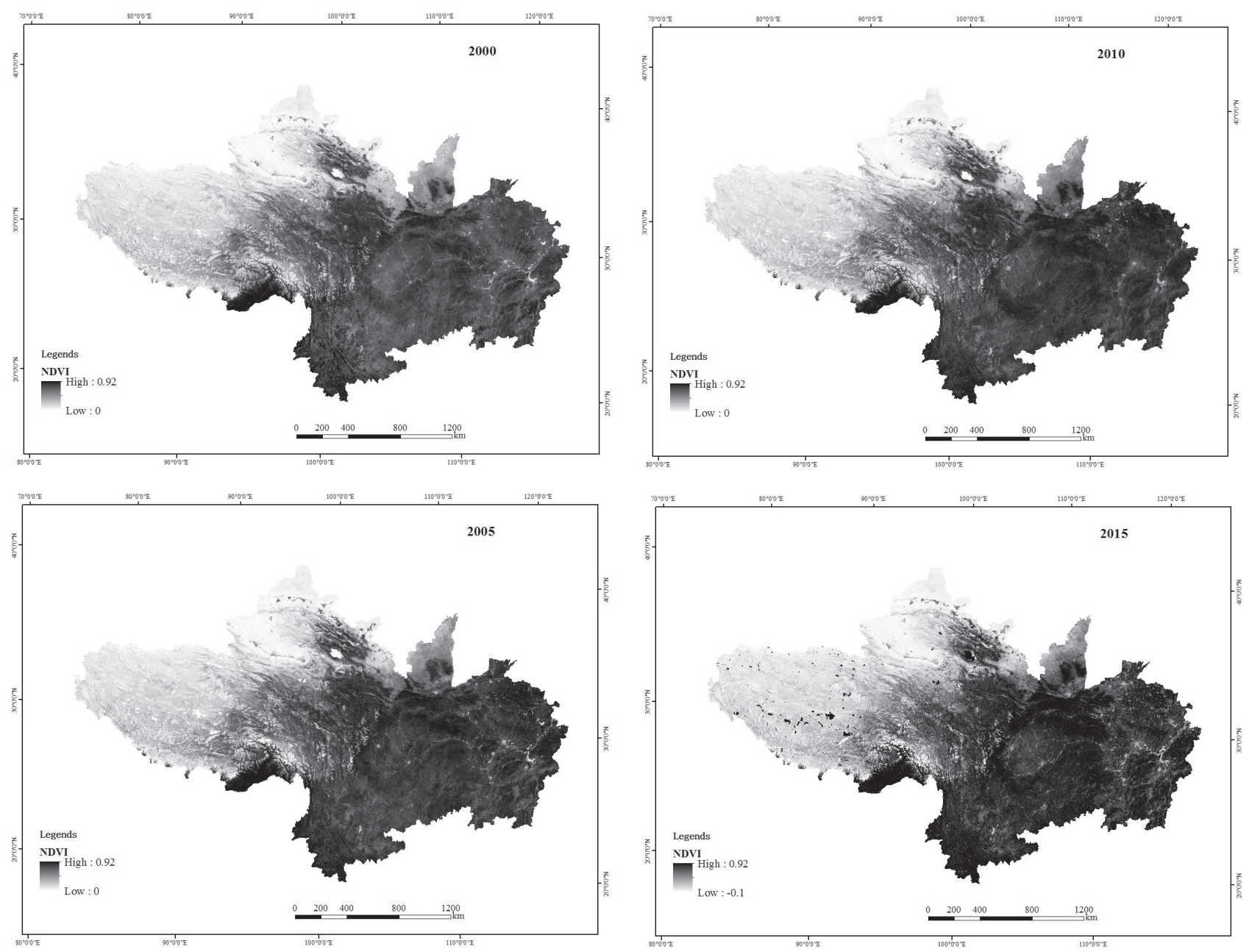

Fig. 3. Normalized difference vegetation index in the upper and middle reaches of the Yangtze River in 2000, 2005, 2010 , and 2015. 


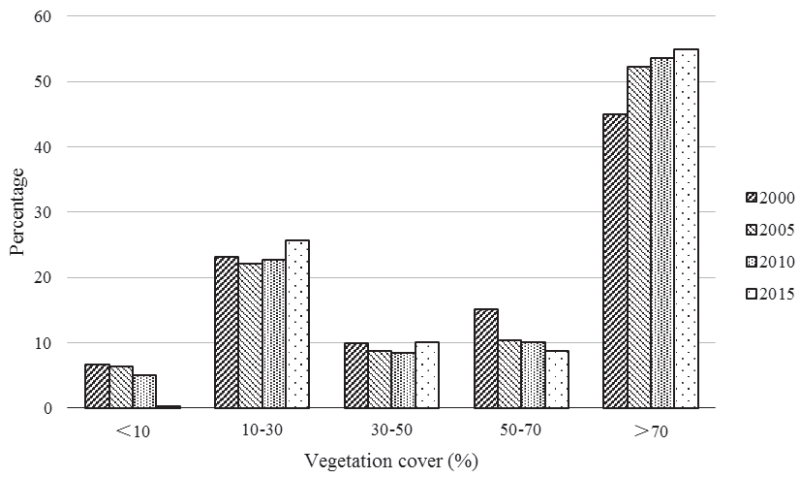

Fig. 4. Changes in the extent of vegetation cover as a percentage of total land area in the upper and middle reaches of the Yangtze River.

the area under low-quality and low-benefit woodlands with canopy density lower than 0.4 increased: most of the quality woodlands were either destroyed or exploited. Secondly, in recent years, and especially in inland areas, the demand for land has increased because of rapid industrialization and urbanization; the state has increased the protection for cultivated land; many land-use projects have been transferred to forest land; and deforestation, encroachment of woodland, and illegal occupation of forest land are becoming more and more serious. For example, according to the forestry department of Sichuan Province, $6416 \mathrm{hm}^{2}$ of forest land were expropriated each year on average in Sichuan during 2010-2014.

\section{Extent of Farmland Restored to Woodland}

During 2000-2015, the area under cultivated land comprising steep slopes decreased by 2.59 million $\mathrm{hm}^{2}$ and the extent of cultivated land where the slope was greater than $35^{\circ}$ decreased by $25 \%$. During 2005-2010, the extent of cultivated land decreased by $10,000 \mathrm{hm}^{2}$, and of that where the slope was $25-35^{\circ}$ decreased by $2.68 \%$. Thus, land use underwent extensive conversion during 2000-2005. At the same time, the share of fallow lands on gentle slopes reached 1.61-2.20\%. This kind of change was mainly due to the policy that encouraged reforestation. The restoration and protection of ecosystems and the control of soil erosion and water erosion require that as far as possible, steep slopes be left fallow.

\section{Changes in Vegetation Cover}

The area over which vegetation cover was low decreased substantially compared to that at the early stage of the GGP, whereas the area over which vegetation cover was dense increased markedly (Fig. 4). The area over which the vegetation cover was below $10 \%$ decreased by $95.27 \%$ and that over which the vegetation cover was above $70 \%$ increased by $21.92 \%$. The area over which the vegetation cover was between $10 \%$ and $30 \%$ increased slightly during 2000-2005 and continued to increase gradually over time. The area over which the vegetation cover was between $30 \%$ and $50 \%$ decreased gradually during 2000-2010, but in 2015 it was greater than that in 2000 by $943,500 \mathrm{hm}^{2}$. The proportion of area with vegetation cover between $50 \%$ and $70 \%$ decreased over time, most markedly during 2000-2005, and that with vegetation cover between $50 \%$ and $70 \%$ decreased by $5 \%$. Most of the study area falls in the subtropical monsoon zone, where both precipitation and temperature are suitable and trees are easy to grow and their growth is rapid. Therefore, the vegetation cover in the study area increased significantly and in a short time, although the increase was not uniform over the entire area, because of such factors as climate, planting, requisition of land for forest, and soils.

\section{Changes in Intensity of Soil Erosion}

Compared to the early period of the GGP, soil erosion has been generally brought under control, except in areas where soil erosion was intense (Table 5). Between 2000 and 2015, the area over which soil erosion was mild decreased by $31.92 \%$; that over which it was strong, by $10.88 \%$; and that where it was pole strength, by $19.44 \%$. The area that was subject to moderate soil erosion decreased the most, by $9.31 \%$, during 2000-2005 and then decreased slightly during 2005-2010 - only to increase again during 2010-2015, although overall it was $3,512,500 \mathrm{hm}^{2}$ less than that in 2000. Thus the GGP had checked soil erosion significantly in the middle and upper reaches of the Yangtze, especially on slopes. Over time, as the trees, shrubs, and grasses grow taller, soil erosion in the study area will be controlled even more efficiently. The area under severe soil erosion increased by $600 \mathrm{hm}^{2}$ during 2000-2010 but decreased thereafter such that by 2015 , its extent was close to that in 2000 . This area needs

Table 5. Changes $\left(104 \mathrm{hm}^{2}\right)$ in each grade of soil erosion in the upper and middle reaches of the Yangtze River.

\begin{tabular}{|c|c|c|c|c|c|}
\hline \multirow{2}{*}{ Year } & \multicolumn{5}{|c|}{ Intensity of soil erosion } \\
\cline { 2 - 6 } & Mild & Moderate & Strong & Pole strength & Severe \\
\hline 2000 & 4679.94 & 6717.59 & 389.88 & 27.98 & 0.61 \\
\hline 2005 & 3809.46 & 6091.91 & 367.81 & 25.32 & 0.68 \\
\hline 2010 & 3680.45 & 6067.51 & 377.95 & 28.05 & 0.75 \\
\hline 2015 & 3185.97 & 6366.34 & 347.48 & 22.54 & 0.62 \\
\hline
\end{tabular}



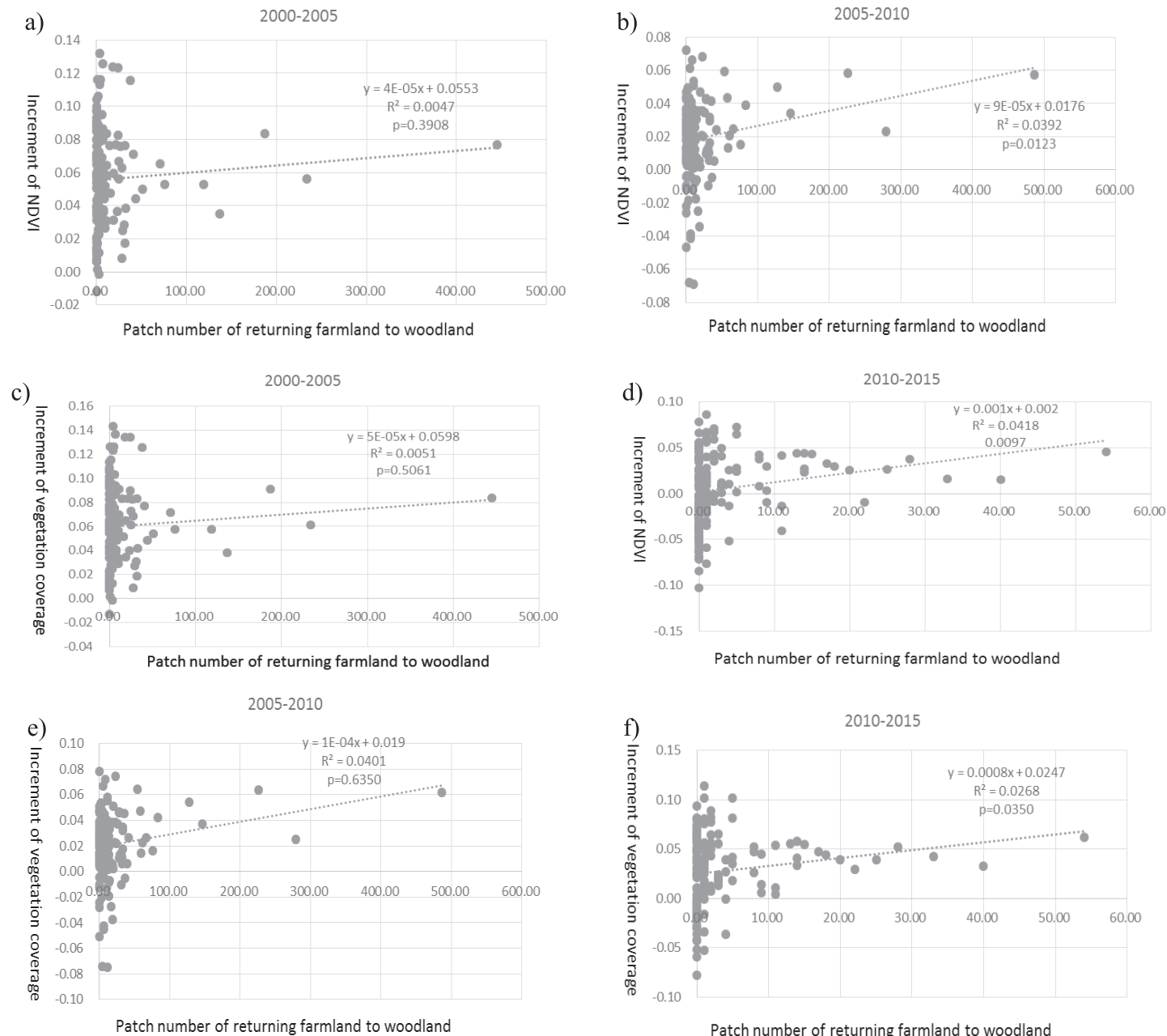

Patch number of returning farmland to woodland
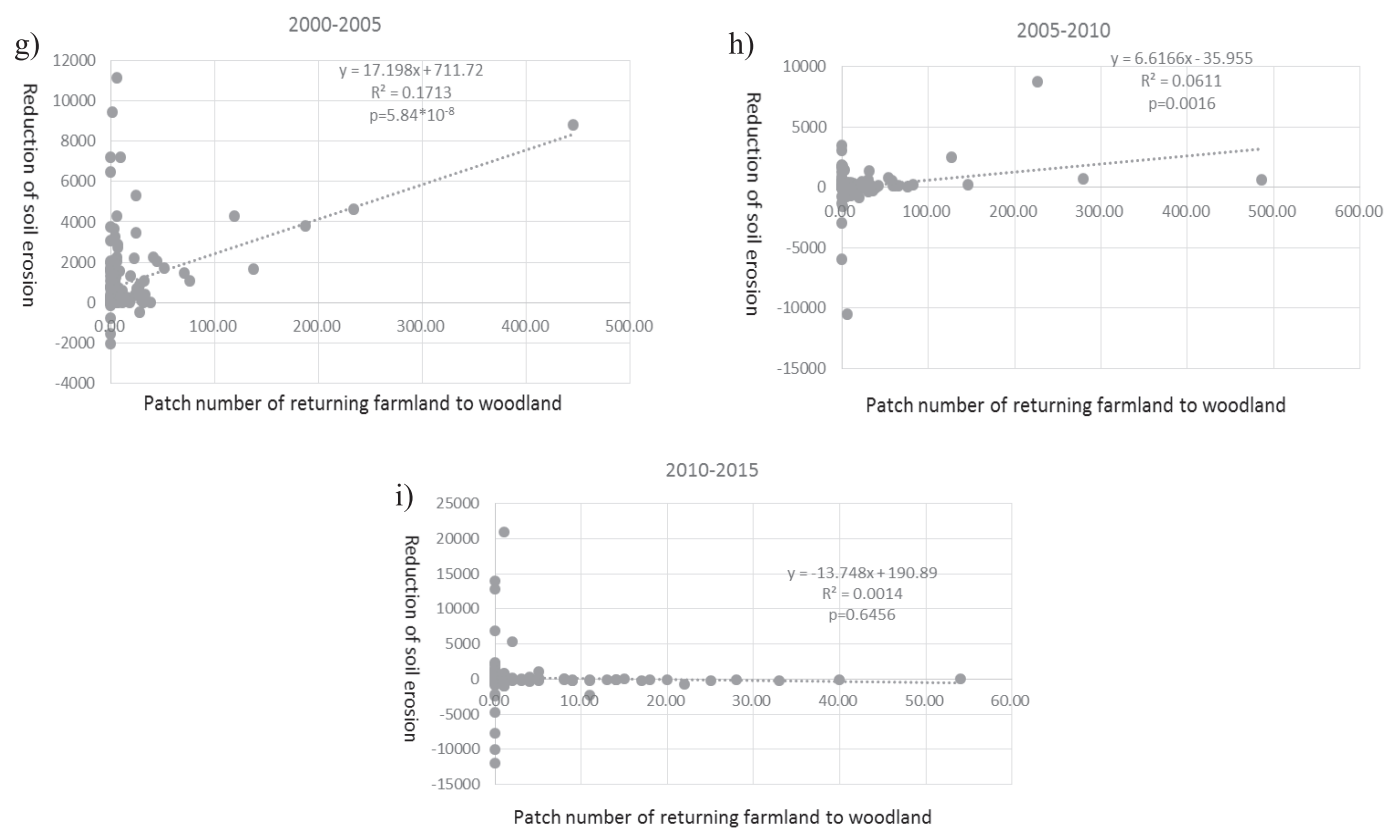

Fig. 5. Linear regression of patch number of returning farmland to woodland with other factors; notes: a) patch number of returning farmland to woodland and increment of NDVI in 2000-2005, b) patch number of returning farmland to woodland and and increment of NDVI in 2005-2010, c) patch number of returning farmland to woodland and increment of NDVI in 2010-2015, d) patch number of returning farmland to woodland and increment of vegetation coverage in 2000-2005, e) patch number of returning farmland to woodland and increment of vegetation coverage in 2005-2010, f) patch number of returning farmland to woodland and increment of vegetation coverage in 2010-2015, g) patch number of returning farmland to woodland and reduction of soil erosion in 2000-2005, h) patch number of returning farmland to woodland and reduction of soil erosion in 2005-2010, and i) patch number of returning farmland to woodland and reduction of soil erosion in 2010-2015. 
greater attention, and the government should strengthen the measures to control soil erosion in the Three Gorges Reservoir area and introduce scientifically and effectively formulated strategies to check the severe soil erosion and to promote ecological recovery of the area.

\section{Correlation Analysis on GGP}

Erosion was significantly reduced during 2000-2005 and was very significantly and positively correlated to the extent of farmland that was returned to woodland, and the correlation was higher than that for any other factors (Fig. 5). Returning farmland to forest was the major change that decreased the area of farmland that consisted of slopes. Peng et al. [35] found that the pattern of vegetation dynamics was markedly affected by topography, especially altitude, and the increase in altitude was closely correlated to the growth of vegetation. The study area lay mainly in the second step (2005-2010) and in the transition zones between the first (2000-2005) and the second step and between the second and the third steps (2010-2015), and returning farmland to forest was confined mainly to cultivated land on steep slopes - which is why the project was successful in increasing the vegetation cover. At the same time, hydrothermal conditions in Yangtze shelter forests were particularly suitable for returning the farmlands to woodlands using such indigenous and fast-growing tree species as Chinese fir and masson pine, which have high survival rates and grow rapidly and are therefore effective in checking the loss of soil and water. However, planting saplings did not increase the NDVI and vegetation cover significantly during this period. The second significant factor correlated to the patch number of farmland returning to woodland are the erosion reduction in 2005-2005 and the addition of NDVI in 2010-2015. Some woodland reforestation and extensive afforestation of barren hills during 2005-2010 and previously planted farmland forest growth can be more effective in the recovery of vegetation. Part of the farmland that was afforested in 2010-2015 now consists of either fully mature forests or those that are halfway to maturity: these patches of good-quality forests increased NDVI significantly.

The other factors were not significantly correlated to the numbers of patches of farmland returned to woodland. The negative correlation between the extent of reduction in erosion and the number of patches of farmland returned to woodland is seen during 2010-2015, but the correlation is the weakest. During 2010-2015, which marks the end of the first round of GGP, the subsidy offered for improving the ecology of farmlands failed to meet the needs of the farmer, who began raising crops. This affected the good ecological environment in the existing forests and destroyed parts of natural forests. In addition, the cancellation of agricultural tax, reforms in the collective rights and the land transfer system, the changed ecology owing to settlements, and the 'One Belt and One Road' also brought in changes to land use. Li et al. [36] believe that exposure of the newly reclaimed farmland to spring weather and irrigation with groundwater are not conducive to soil and water conservation, and may lead to a serious ecological disaster. Large parts of the study area faced natural disasters: 49.89 million hectares during 2000-2005, 40.10 million hectares during 2005-2010, and 44.64 million hectares during 2010-2015, thereby increasing soil erosion.

\section{Conclusions}

1) The Yangtze River shelter forest region in recent years benefitted a great deal from GGP, with marked improvement in the region's ecological environment. Cultivated lands were converted into woodlands and grasslands, forest cover increased significantly, and large parts of cultivated lands on steep slopes were returned to woodland. The extent of low vegetation cover was greatly reduced whereas that of denser cover increased significantly. The intensity of soil erosion decreased overall, and the area suffering from mild, strong, and pole-strength grades of soil erosion also decreased markedly - the benefits of GGP being obvious in terms of soil and water conservation.

2) The experience of restoring vegetation in the middle and upper reaches of the Yangtze in recent years indicates that self-repair of vegetation is an important way to improve ecology and the environment. At present, forests cover $60 \%$ of the middle and upper reaches of the Yangtze, the cover being greater to the east of the river and low to its west. The extent of vegetation cover varies over time because of replanting, deforestation, and land acquisition. The next phase of the GGP should emphasize more vigorous implementation of the project in the upper reaches of the Yangtze; facilitate afforestation in the middle reaches to maintain the existing cover and to promote the transformation of created forests to nearnatural forests; and encourage a mix of vegetation comprising trees, shrubs, and grasses.

3) To confirm the GGP results, this study needs to be supplemented with field studies to establish the ground truth more accurately and to identify and calculate the area and spatial distribution of farmland converted to forests.

The shortcomings of this study are as follows:

- The causes of changes following the implementation of the Grain to Green Project could have been analyzed and understood more clearly if we had used higherresolution remote sensing images and supplemented that approach with studies on the ground.

- The administrative regions were not defined with adequate precision.

- On a large scale, it is impossible to distinguish clearly between the effects of the Grain to Green Project and those of other ecological engineering measures, and the present research did not take into account the effects of government policy and those of the behavior 
of individual farmers. It is advisable to divide the area under the Grain to Green Project into distinct ecological zones before undertaking more research on the topic.

\section{Acknowledgements}

This work was financially supported by grants from the Beijing Municipal Education Commission (PXM2017_014207_000043) and subsidized by CFERN \& GENE Award Funds on Ecological Papers. Funding agencies were involved in the data collection and analysis, and participated in the consultation regarding the decision to publish this paper.

\section{Conflict of Interest}

The authors declare no conflict of interest.

\section{References}

1. CAO S., CHEN L., LIU Z. An investigation of Chinese attitudes toward the environment: Case study using the Grain for Green Project. AMBIO: A Journal of the Human Environment, 38 (1), 55, 2009.

2. PERSSON M., MOBERG J., OSTWALD M., XU J. The Chinese Grain for Green Programme: Assessing the carbon sequestered via land reform. Journal of environmental management, 126, 142, 2013.

3. WANG B., GAO P., NIU X., SUN J. Policy-driven China's Grain to Green Program: Implications for ecosystem services. Ecosystem Services, 27, 38, 2017.

4. LEI D.E.N.G., SHANGGUAN Z.P., RUI L. . Effects of the grain-for-green program on soil erosion in China. International Journal of Sediment Research, 27 (1), 120, 2012.

5. UCHIDA E., XU J., ROZELLE S. Grain for green: cost-effectiveness and sustainability of China's conservation set-aside program. Land Economics, 81 (2), $247,2005$.

6. LONG H.L., HERLIG G.K., WANG J., LI X.B., LUO M., WU X.Q., ZHANG M. Land use and soil erosion in the upper reaches of the Yangtze River: some socio-economic considerations on China's Grain-for-Green Programme. Land Degradation \& Development, 17 (6), 589, 2006.

7. ZHOU Z. C., GAN Z.T., SHANGGUAN Z.P., DONG Z.B. China's Grain for Green Program has reduced soil erosion in the upper reaches of the Yangtze River and the middle reaches of the Yellow River. International Journal of Sustainable Development \& World Ecology, 16 (4), 234, 2009.

8. DENG L., LIU G.B., SHANGGUAN Z.P. Land-use conversion and changing soil carbon stocks in China's 'Grain-for-Green'Program: a synthesis. Global Change Biology, 20 (11), 3544, 2014.

9. CHEN X., ZHANG X., ZHANG Y., WAN C. Carbon sequestration potential of the stands under the Grain for Green Program in Yunnan Province, China. Forest Ecology and Management, 258 (3), 199, 2009.
10. WANG J., PENG J., ZHAO M., LIU Y., CHEN Y. Significant trade-off for the impact of Grain-for-Green Programme on ecosystem services in North-western Yunnan, China. Science of the Total Environment, 574, 57, 2017.

11. LONG H.L., HERLIG G.K., WANG J., LI X.B., LUO M., WU X.Q., ZHANG M. Land use and soil erosion in the upper reaches of the Yangtze River: some socioeconomic considerations on China's Grain-for-Green Programme. Land Degradation \& Development, 17 (6), 589, 2006.

12. TUCKER C.J., FUNG I.Y., KEELING C.D., GAMMON, R.H. Relationship between atmospheric $\mathrm{CO}_{2}$ variations and a satellite-derived vegetation index. Nature, 319 (6050), $195,1986$.

13. COSTANTINI M.L., ZACCARELLI N., MANDRONE S., ROSSI D., CALIZZA E., ROSSI L. NDVI spatial pattern and the potential fragility of mixed forested areas in volcanic lake watersheds. Forest ecology and management, 285, 133, 2012.

14. WANG J., WANG K., ZHANG M., ZHANG C. Impacts of climate change and human activities on vegetation cover in hilly southern China. Ecological Engineering, 81, 451, 2015.

15. PENG S., CHEN A., XU L., CAO C., FANG J., MYNENI R.B., PIAO S. Recent change of vegetation growth trend in China. Environmental Research Letters, 6 (4), 044027 , 2011.

16. PIAO S., FANG J., ZHOU L., GUO Q., HENDERSON M., JI W., TAO S. Interannual variations of monthly and seasonal normalized difference vegetation index (NDVI) in China from 1982 to 1999. Journal of Geophysical Research: Atmospheres, 108 (D14), 2003.

17. YAGOUB Y.E., LI Z., MUSA O.S., ANJUM M.N., WANG F., XU C., BO Z. Investigation of Vegetation Cover Change in Sudan by Using Modis Data. Journal of Geographic Information System, 9 (03), 279, 2017.

18. JIANG M., TIAN S., ZHENG Z., ZHAN Q., HE Y. Human Activity Influences on Vegetation Cover Changes in Beijing, China, from 2000 to 2015. Remote Sensing, 9 (3), 271, 2017.

19. HAO W., GUOHA L., ZONGSHAN L., XIN Y., BOJIE F., YIHE L. Analysis of the Driving Forces in Vegetation Variation in the Grain for Green Program Region, China. Sustainability, 9 (10), 1853, 2017.

20. LV Y., ZHANG L., FENG X., ZENG Y., FU B., YAO X. WU B. Recent ecological transitions in China: greening, browning, and influential factors. Scientific reports, 5, 2015.

21. FENG X., FU B., LU N., ZENG Y., WU B. How ecological restoration alters ecosystem services: an analysis of carbon sequestration in China's Loess Plateau. Scientific reports, 3, 2013.

22. ZHANG G., DONG J., XIAO X., HU Z., SHELDON S. Effectiveness of ecological restoration projects in Horqin Sandy Land, China based on SPOT-VGT NDVI data. Ecological Engineering, 38 (1), 20-29, 2012.

23. YAGOUB Y.E., MUSA O.S., SIDDIG A.A., BO Z., LI Z., WANG F. Assessing the Impacts of Land Use Changes on Vegetation Cover in Eastern Sudan. International Journal of Research in Agricultural Sciences, 4, 70, 2017.

24. YAN L., HE R., KASANIN-GRUBIN M., LUO G., PENG H., QIU J. The Dynamic Change of Vegetation Cover and Associated Driving Forces in Nanxiong Basin, China. Sustainability, 9 (3), 443. 2017. 
25. ZHANG B., WU P., ZHAO X. Detecting and analysis of spatial and temporal variation of vegetation cover in the Loess Plateau during 1982-2009. Transactions of the Chinese Society of Agricultural Engineering, 27 (4), 287, 2011

26. WANG X.F., REN Z. . Study on dynamic change of vegetation coverage in Yulin city based on RS and GIS. Journal of Shaanxi Normal University (Natural Science Edition), 36 (3), 1014, 2008

27. DENGKE L., JING Z., ZHIHUI S. Monitoring the effects of ecosystem restructuring project after returning farmland to forest based on RS and GIS. Transactions of the Chinese Society of Agricultural Engineering, 12, 2008.

28. YANG G., SUN B.P., ZHAO T.Y., DING G.D., HE D.Y. The effects of returning cropland to forest on re-vegetation in loess hilly region. Journal of AridLand Resources and Environment, 20 (2), 165, 2006.

29. LAI Y.F., ZHU Q.K., ZHANG Y.Q., QIN W., LI W.H. Valuing ecological effects of land conversion project in wuqi county. Soil and Water Conservation Journal, 20 (3), 83,2006

30. LUO Z.G., ZHAO T.Y., WANG X., SUN B.P., CAO Z.L. Study on revegetation effect of returning farmland to forestry combining closure in sand covered and loess region in wuqi county. Research of Soil and Water Conservation, $13(3), 80,2006$
31. SUN Z.H., LEI Y.P., ZHUO J., CAO X.M., LIU Z.C., LI D.K. Remote sensing analysis of the effectiveness of converting farmland into forest or grass in the hilly gully region of Northern Yanan. Acta Ecologica Sinica, 30 (23), 6555, 2010

32. PENG J., LIU Y., SHEN H., HAN Y., PAN Y. Vegetation coverage change and associated driving forces in mountain areas of Northwestern Yunnan, China using RS and GIS. Environmental monitoring and assessment, 184 (8), 4787, 2012.

33. IBRAHIM Y.Z. Vegetation and Land Cover Change in the Context of Land Degradation in sub-Saharan West Africa. Department of Geography, 2017.

34. WANG B., GUO Q.S., YANG F.W., JIANG Y.X., LIU S.R., CUI, X.H., Indicators System for Long-Term Observation of Forest Ecosystem (LY/T 1606-2003). Standards Press of China, Beijing, 2003.

35. PENG J., LIU Z., LIU Y., WU J., HAN Y. Trend analysis of vegetation dynamics in Qinghai-Tibet Plateau using Hurst Exponent. Ecological Indicators, 14 (1), 28, 2012.

36. LI S., WANG T., YAN C. Assessing the role of policies on land-use/cover change from 1965 to 2015 in the Mu Us Sandy Land, northern China. Sustainability, 9 (7), 1164, 2017. 